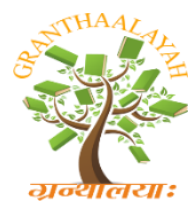

INTERNATIONAL JOURNAL OF RESEARCH GRANTHAALAYAH A knowledge Repository

Science

\title{
USING INFORMATION SYSTEMS AND TECHNOLOGIES IN HIGHER EDUCATION INSTITUTIONS
}

\author{
Haydar Ateş ${ }^{* 1}$ \\ ${ }^{* 1} \mathrm{PhD}$, University of Turkish Aeronautical Association, Turkey
}

\begin{abstract}
The rapid development in technology has provided the globalization and to facilitate the exchange of information. The importance of tertiary education has been increasing due to its contribution for development plan's manpower requirements in quality and quantity. Developments in information systems and technology have provided significant opportunities for higher education institutions. In this research; the implementation and development of information systems and technology in higher education institutions are chosen as a problem in comparison with global scale and taking into account the development of proposals. In this context; the developed countries' higher education institutions' were examined, after then universities' information systems and technologies' current status and degree of functionality are compared, and finally the proposals were developed. For this purpose; higher education institutions' level of readiness for etransformation, information technologies' contribution to today's class and on the quality of education in shaping the contribution of higher education to shape the future and global competition ready workforce, the growing importance of information technologies on distance learning and on lifelong learning, higher education institutions' role, and contribution to development of information technology, and the contribution of the envisaged objectives of the development plan.
\end{abstract}

Keywords: Technology Usage in Higher Education; Information System; Information Technology.

Cite This Article: Haydar Ateş. (2019). "USING INFORMATION SYSTEMS AND TECHNOLOGIES IN HIGHER EDUCATION INSTITUTIONS." International Journal of Research - Granthaalayah, 7(10), 222-232. 10.29121/granthaalayah.v7.i10.2019.390.

\section{Introduction}

Information systems are used in organizations; to collect, store, process, deliver or distribute the collected or produced information to users in order to support decision making, planning, coordination, communication, analysis and animation, implementation, audit and evaluation, which are sub-functions of management can be defined as a set of related parts.

This age is called as "information age" due to new terms, "information society" and "knowledge management". The capability of producing and using information appropriately in all areas will 
provide superiority for the society thanks to constantly increasing investment in education. In this information age, the knowledge and well-educated manpower are indicators for wealth of the country.

The use of information technologies is gaining new dimensions day by day and continues to affect life significantly. The changing world order, by bringing out the concept of globalization, as in other sectors, in the education sector, both national and international areas such as quality and competition are brought to the agenda.

It is one of the most important parts of the emergence and development of information technologies, and the main areas in which the information is spread and its importance is the use of computers; industry, commerce, education, engineering, the vast majority of banking operations, medical field, research and development (R\&D) studies, science, social sciences, space research, cartography and architecture, art, media, houses. New areas are being added to these areas day by day and they are moving towards becoming the constant part of life.

The opportunities provided by the information system and technology, as in other educational institutions, push higher education institutions to provide more efficient and efficient services in the global environment. Research and development (R\&D) have come to the forefront today, while education has been focused on learning and information acquisition until recently. This necessitates maximum use of information technology in order to reach all the information produced on certain subjects and to deal with all aspects of the subject. Recent advances in information technology require access to the right information as well as providing the information in the right place, at the right time, in a fast, up-to-date and integrated manner.

Higher education institutions are the pioneers of the institutions that play the most important role in the information age and information societies. Because these institutions; is responsible for the production and distribution of information, which is the raw material of the information society. ICT affects all other institutions and organizations as well as higher education institutions. The importance of ICT for these institutions can be better understood if we take into account the place and importance of ICT in today's education and R\&D, where most of the students and faculty members in these institutions were foreigners until recently.

It is not enough for higher education institutions to establish information and communication technology(ICT)solely for their internal needs; at the same time, to ensure the exchange of information with all other institutions and organizations of similar structure, to follow the developments and new requirements in the sectors in which the trained manpower will work, to include them as feedback in the education process, and to develop the system in accordance with the requirements such as contributing to the lifelong learning needs of the graduates.

Today, ICT is used in all areas of teaching and learning in universities. However, research shows that in the installation of these systems, the internal needs of higher education institutions are generally prioritized (Bates, 2000; Cole, 2000; Ransom, Graham and Mott, 2007; Price and Oliver, 2007). 
The use of ICT in teaching and learning process in universities is a social and organizational phenomenon. Social and organizational theories state that it is appropriate to take into account all micro and macro factors affecting the system to be established (Layder, 1993). In the installation of these systems; there are also opinions indicating that it would be more appropriate to address the issue on an individual, organizational and social basis.

The use of ICT in universities in the big change experienced by contemporary society; It is a factor that needs to be addressed and evaluated with its contributions to facilitate education, timedependent educational actions and access, reduce training time, and reduce costs by increasing quality (Price and Oliver, 2007). Researchers advocating the effectiveness of ICT; they state that the capacity of the technology will provide better access to educational processes, regardless of time and space. When it comes to improving quality in education, some researchers argue that this can be achieved through effective use of technology (Beers, 2007). Some researchers, contrary to this idea, use ICT in education; access, quality and cost. Another important issue is how to reach the required skill level for those who need access to technology for education (Bates, 2000).

Considering the important facilities provided by ICT organizations; the benefit of the universities, where these issues are the most intense, will be better evaluated. BIT; It can store large-scale data with the least cost and minimum space requirement, adjust the storage areas of these data and provide access in a very short time when requested. It allows a large number of users to reach the integrity of the data without disturbance and confusion. It provides an advantage for managers and planners to maximize the performance of the system and to establish a more effective management system, saving more time for their essential tasks.

One of the most important features of ICT is that it can work continuously for a long time and there is no decrease in performance during this period, it enables access from anywhere according to the characteristics of the system, thus facilitating access to information at the desired time and quality. According to the security system used; In accordance with the principle that users need to know, they can only access the information they are authorized to, although the location where the information is stored is the same, it allows to limit accessors when necessary or to prevent unauthorized access.

The level of higher education institutions in countries to use ICT effectively; In addition to being one of the indicators of the level of development of that country, it is also an indicator of its competence in using knowledge and producing new knowledge and raising manpower ready for global competition. As important external factors affecting the level of use of ICT by universities; The level at which ICT has reached and the degree of contribution to the university system, the policies of governments and the resources they have allocated for this purpose, the expectations of the industry from the universities and the degree of the desire of the universities to respond to these expectations, the level of demand for universities can be said. Among the internal factors that affect the spread and use of ICT in the university; the attitude of the management level, academic work and cultural environment, the attitude of the faculty members, the interest in the use of technology. 


\section{Methodology}

The research is descriptive and qualitative research methods are used predominantly. In the collection of data; national and international any literature review" and "observation" methods were used. For the collected data, "content analysis" was conducted and in order to facilitate the analysis, the data were divided into two main theme groups as "information systems" and "information technologies, and the analysis was based on comparative education method and qualitative analysis techniques. With the data obtained; A descriptive analysis framework was formed, processed according to the thematic framework, and the results were defined and interpreted.

\section{Findings and Interpretation}

ICT integration into teaching methods and programs has traditionally been a very long and slow process (Roblyer, 2004). On the other hand, the technology in everyday life is moving at a dizzying pace, which requires attention to the timing of ICT-related education policies. ICT-related policies; infrastructure, resource management, learning, teaching, personal development, in-service training, implementations and decisions related to major reforms (Knowles, 2004).

Debande (2004) emphasized that the following factors should be taken into consideration for the successful implementation of ICT:

- Infrastructure and equipment,

- High quality educational multimedia services and content,

- Training activities for teachers and lifelong learning activities,

- Dialogue and cooperation at all levels.

This shows us that ICT policies in higher education institutions include not only decisions about hardware such as computers, other technological equipment and the Internet, but also some other factors such as in-service training of the staff, social dialogue and understanding. Integration of ICT into education within the education system; managers, teaching staff and students.

It is seen that ICT has been given more importance especially in the education policies of the European Union (EU) and higher education institutions within the last 20-25 years. Following the developments in this field since the 1980s, necessary decisions were taken. However, implementation-oriented studies could not be carried out until 2000s. In this process, computers and various technologies were purchased to universities, simple education portals and local area networks were established and academic and administrative personnel were provided with inservice training.

With the rapid expansion of ICT after 1995 and the introduction of personal computers into all areas, significant progress has been made in this field. Important and concrete decisions have been taken in order to enable citizens to be digital literate, to use ICT in education and to exchange information and experience with national and international networks of higher education institutions. In this context; computer equipment was installed in all higher education institutions, internet access was provided and their participation in the local, national and international higher education network system was encouraged. In-service training support for the development of this 
system was provided. The EURYDICE portal, which includes comprehensive data on the education systems of EU countries, has been created with the EURYBASE database connected to this system and made available to all higher education institutions and individual researchers.

By the European Union (EU); the new world order and the situation facing Europe are expressed in a report, the majority of which consists of decisions on the use and dissemination of Information and Communication Technologies in education systems (Education Council, 2001):

"Today's world is characterized by rapid change, increasing globalization and increasing complexity in economic and socio-cultural relations. The speed of these changes should be reflected and included in the future objectives of the education and training systems. New economic structures and societies are increasingly being governed by knowledge. In particular, computers continue to be used more at work and at home, revealing the need to become more familiar with Information and Communication Technology (ICT) and better use ICT, education and training."

ICT is currently used in higher education institutions in EU and other developed countries for the following purposes;

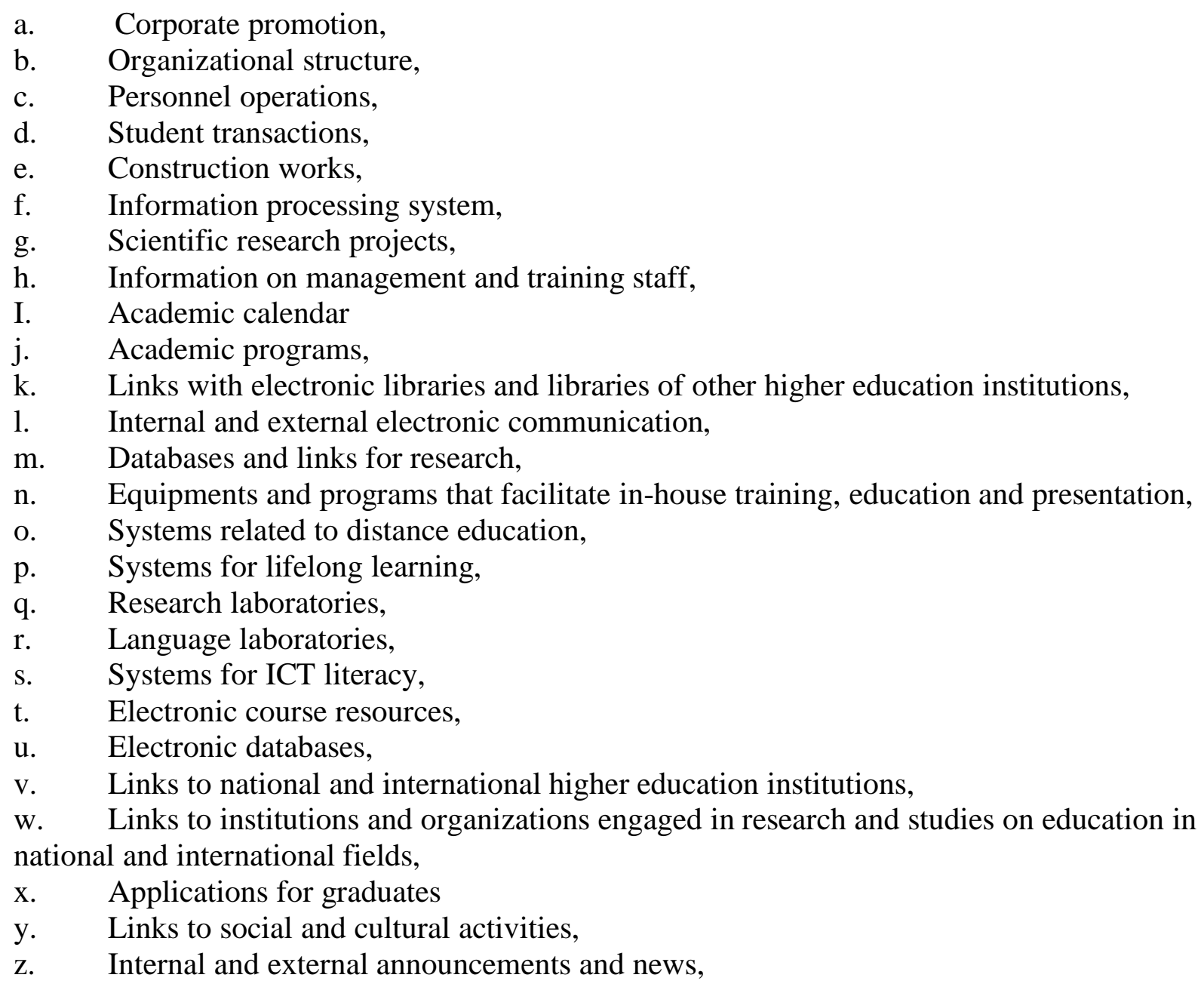


aa. Links and information about life systems in higher education institutions,

bb. Feedback system for education,

cc. Connections with other social systems and physical environment.

Except the specified fields; there are additional usage areas according to the characteristics of each higher education institution. Basic understanding; to use ICT at the highest level in order to get the best results in education and training and to perform the operation of the system at the lowest cost.

The first major initiative for information and communication technologies in higher education policy in Turkey; Turkey Scientific and Technological Research Council (TUBITAK) in established in 1996 as an institute of the National Academic Network and Information Center (ULAKBIM). ULAKBİM, all higher education institutions and research centers are operating with each other and international higher education system at the national level and the higher education network linking research institutions and offers R\&D infrastructure for researchers in Turkey. Institution; by Cahit Arf Information Center, the richest scientific printed and electronic information sources in Turkey offers the service.

The inclusion of ICT in the Turkish National Education System has a new history. 1980s have been raised several projects and initiatives since the middle, covered put E-Turkey study revealed in 2003 "E-Transformation Turkey Project" with more advanced policies for bits and targets has been raised (Keskinkılıç, 2003).

National policies for ICT; the state has opened the way for development in higher education institutions, budget resources for the establishment of these systems have been increased. Currently, ICT in higher education institutions, although different applications in some higher education institutions, generally consists of 6 main modules and sub-services within these modules.

These modules and sub-modules; student affairs (pre-registration, first registration, medical procedures, teaching staff grade entry, student transactions and web registration procedures, etc.), personnel jobs (hospital and leave procedures, academic staff CVs, registration procedures, additional course module, salary jobs), scientific research projects (procurement and management), construction works, information processing system (electronic communication, software support, management system, etc.). Higher Education Institutions web pages; As in other developed countries, ICT facilities are being used for the purposes listed above.

Higher education institutions in Turkey, as in other developed is entered here, the technology's high level and there are institutions that are frequently used and at senior management level in this regard although the request at the user level with the necessary willpower, research on not achieved the productivity desired application is available.

In Turkey, over the degree of use in education, issues affecting the use of computer effects of the assisted training and enough research and objective information on the adequacy of the field of inservice training programs for this subject is not yet sufficient. But; the issue agreed is that ICT has the potential to open new horizons for the education system and that despite the technological 
support provided to educational institutions through various projects, its contribution to education is not at the desired level and will remain limited for a long time.

According to international researches; The reasons for not being able to use ICT effectively and as problems encountered in use; the lack of knowledge and skills of the educational staff yet, the lack of hardware and software. Also; The rapid development in technology adversely affects the renewal and efficiency of these very expensive systems. Some higher education institutions are struggling to renew ICT, which serves a limited number of users, previously established, with relatively old technology and difficulty in adapting to each other. Developing ICT enables the development of widespread, inexpensive and easy to use information systems. This rapid change and development in ICT also complicates the in-service training of user personnel, and the time allocated to this training may be at the expense of the time allocated for training.

Considering some difficulties that prevent the effective use of ICT in higher education institutions; It is seen that the number of computers planned for the use of the teaching staff and especially the students and the internet connection are very limited. Depending on the level of ICT literacy of the staff, a significant portion of the existing computers are mostly used as electronic typewriters and the capacity of the computer is not sufficiently utilized. For this reason, most information and documents are still presented or processed on paper. Although significant investments have been made in systems such as personal computers, communication infrastructure and electronic communications, it is difficult to say that the investments are fully reimbursed.

In the majority of state higher education institutions in Turkey are of course registration is done on computers, students can say they are unable to provide their homework electronically. Despite the important facilities provided by ICT; issues such as initial registration, renewal of registrations, follow-up of tuition and tuition fees, follow-up of military service of students, production of most frequently used documents in electronic environment have not been fully provided yet. Although most of the higher education institutions offer course content on their web sites; It is seen that the education staff did not put all the reading lists and educational materials on these pages or there were delays in updating them.

In higher education institutions, in the use of information technologies; Although there are policy documents and projects based on developing students' communication, learning and thinking skills and habits and raising them in accordance with the requirements of the information age, it would be appropriate to update the documents, in practice, resource allocation is not sufficient, and the effective use of information and management it was not quantified yet. In this context; It has emerged that information technology should be given importance and priority in the development of non-formal education used within the scope of lifelong learning, which has an important contribution to the transformation of formal education and information society in higher education institutions. Although the targets have been set at the national level, it is seen that higher education institutions have to use their own resources heavily in the realization of projects related to information systems and that the targets have been postponed due to lack of resources.

The fact that IT sector is in constant change and development using dynamic nature of the movement, developing countries located between Turkey globalization and the importance of higher education to the training of manpower required by global competition gradually increased 
from the fact that in mind, the policy for information systems with strategic sectors and projects are evaluated by constantly need to be developed. In this context, in Turkey "Project of Strengthening Vocational Education and Training System" (SVET) similar projects to be implemented in institutions of higher education should be given to implementation of projects in higher education institutions that have emerged.

\section{Conclusion and Suggestions}

As a result; It has been evaluated that there are problems in the dissemination and effective use of information systems in higher education institutions. These; IT vision and the policies and objectives formed in accordance with the vision are not yet at the level of developed countries, quality and standardization is not at the desired level with the pursuit of technology, institutionalization has not been achieved and dissemination has not yet reached the national level. In order for ICT to be established and used in accordance with the needs of institutions of higher education, considering external and internal factors; projects related to the planning, implementation and evaluation of ICT, particularly R\&D, should be developed. The most important issue to be considered in these projects is; to envision talents that must be acquired in the 21 st century, trained manpower ready for global competition.

Information technology; Considering its importance in creating, collecting, processing, disseminating and protecting information, the rate of use as an auxiliary tool in the education provided in higher education institutions should be increased. Because these institutions are the institutions that lead to social change and development. Therefore; continuously monitor, use, learn and teach information technologies.

On the basis of the fact that distance education, which is used extensively in higher education institutions in developed countries, is not at the desired level in institutions in both countries; Inadequate information infrastructure, inadequate legislation in line with the requirements of the era, insufficient investments and incentives, insufficient public opinion for the importance of the system, and especially the managers in the decision-making process do not have sufficient information infrastructure.

Considering that the effective use and even production of ICT in higher education institutions will give a great impetus to the studies related to the subject, it has emerged that the necessary infrastructure should be prepared for universities to gain respectability and become preferable all over the world.

The units that constitute the main backbone of educational institutions such as faculties; to the student, administrative and academic staff to whom they are responsible; and it is important to provide an effective and efficient website in order to carry out the duties it is responsible to the individuals and institutions that want information about the faculty from outside.

In summary; the state of information systems and technologies in state higher education institutions have not yet reached the standards of developed countries, the vision and policy documents related to the subject need to be updated and targets, programs and projects should be developed according to the prepared documents, the existing systems can not be used effectively 
and efficiently, the administrator can use these systems, educators and managers it is necessary to better educate the cadres, to design the systems by considering the current and future needs in the installation of the systems and thus to prevent wasting of resources, and to work on the use of information systems in a way to reduce the financial costs without decreasing the quality of education in higher education. Also; It was evaluated that the application of developed country technologies, the establishment of data sharing information systems, the use of high-performance micro technologies and the integration of these systems into education were evaluated.

\section{References}

[1] Adam, L. (2003). Information and Communication Technologies in Higher Education in Africa: Initiatives and Challenges. Journal of Higher Education in Africa.

[2] Adesola, A. (1991). The Nigeria University: Meeting the Challenges of Growth in a Depressed Economy. Higher Education.

[3] Aldrich, H. E. (1979). Organizations and Environments. Englewood Cliffs, NJ, Prentice-Hall.

[4] Altbach, P. (1990). Perspectives on Comparative Higher Education: Essays on Faculty Students and Reform. Special Studies in Comparative Education, No. 22. Buffalo, New York: Comparative Education Center, SUNY.

[5] Altbach, P. (2005). Patterns in Higher Education Development. In P. Altbach, R. Berdahl, P. Gumport (Eds.). American Higher Education in the Twenty-First Century: Social, Political, and Economic Challenges, 15-37. Baltimore: The Johns Hopkins University Press.

[6] Barret, S. (1999) Information Systems: An Exploration of the Factors Influencing Effective Use. Journal of Research on Computing in Education, Fall 1999, Cilt. 32, No.1.

[7] Bates, A. (2007). Strategic Planning for E-learning in a Polytechnic. In M. Bullen \& D. Janes (Eds.). Making the Transition to E-Learning: Strategies and Issues, 47-65. Hershey, PA: Information Science Publishing.

[8] Bates, A. (2000). Managing Technological Change: Strategies forAcademic Leaders. San Francisco: Jossey Bass.

[9] Becher, T. ve Kogan, M. (1992). Process and Structure in Higher Education (2 ${ }^{\text {nd }}$ ed.). London: Routledge.

[10] Becher, T. (1989). Academic Tribes and Territories: Intellectual Inquiry and the Cultures of Disciplines. Milton Keynes: The Society for Research into Higher Education and Open University Press.

[11] Becher, T. (1987). Disciplinary Shaping of the Profession. In B.R. Clark (Ed.), The Academic Profession: National, Disciplinary, and International Settings. Berkeley. University of California Press.

[12] Becher, T. ve Kogan, M. (1992). Process and Structure in Higher Education (2 ${ }^{\text {nd }}$ ed.). London: Routledge.

[13] Beers, M. (2007). Using E-Learning to Promote Excellence in Polytechnic Education. In M. Bullen \& D. Janes (Eds.). Making the Transition to E-Learning: Strategies and Issues, 66-83. Hershey, PA: Information Science Publishing.

[14] Bergquist, W. ve Pawlak, K. (2008). Engaging the Six Cultures of the Academy. San Francisco: Jossey-Bass.

[15] Biglan, A. (1973). The Characteristics of Subject Matter in Different Academic Areas. Journal of Applied Psychology.

[16] Blackman, C. ve Segal, N. (1992). Industry and Higher Education. In B.R. Clark and G. Neave (Eds.). The Encyclopedia of Higher Education. Oxford: Pergamon.

[17] Brabazon, T. (2002). Digital Helmlock: Internet Education and the Poisoning of Teaching. Sydney: UNSW Press. 
[18] Buchbinder, H. (1993). The Market Oriented University and the Changing Role of Knowledge. Higher Education.

[19] Carnoy, M. (1985). The Political Economy of Education. International Social Science Journal.

[20] Cerych, L. (1984). The Policy Perspective. In B.R. Clark (Ed.). Perspectives on Higher Education: Eight Disciplinary and Comparative Views. Berkeley: University of California Press.

[21] Clark, B. (1983). The Higher Education System: Academic organization in Cross-National Perspective. Berkeley: University of California Press.

[22] Clark, B. (1984). Introduction. In B.R. Clark (Ed.). Perspectives on Higher Education: Eight Disciplinary and Comparative Views, 1-16. Berkeley: University of California Press.

[23] Cole, R. (2000). Issues in Web-Based-Pedagogy: A Critical Primer. Westport, CT: Greenwood.

[24] Dabbagh, N. ve Bannan-Ritland, B. (2005). Online Learning: Concepts, Strategies and Application. NJ: Prentice-Hall.

[25] Daniel, J. (1997). Why Universities Need Technology Strategies.

[26] Denison, E. (1962). The Sources of Economic Growth in the United States and the Alternatives Before Us. New York: Committee for Economic Development.

[27] DEÜ. Erişim: 10.08.2014. http://www.deu.edu.tr/DEUWeb/Icerik/Icerik.php?

[28] Dore, R. P. (1976). The Diploma Disease: Education, Qualification and Development. London: George Allen \& Unwin.

[29] Epper, R. M. ve Bates, A. (2001). Teaching Faculty How to Use Technology: Best Practices From Leading Institutions. Westport CT.: American Council on Education/Oryx Press.

[30] Erkut, H., (2000) Analiz, Tasarım ve Uygulamalı Sistem Yönetimi, No. 4, İstanbul: İrfan Yayımcilik.

[31] Gökçen, H., (2007) Yönetim Bilgi Sistemleri, Ankara: Palme Yayıncılık.

[32] Hannan, M. T. ve Freeman, J. H. (1977). The Population Ecology of Organizations. American Journal of Sociology.

[33] Headrick, R. D. (2002) Enformasyon Çağı Akıl ve Devrim Çağında Bilgi Teknolojileri (Çeviren: Zülal Kılıç), İstanbul: Kitap Yayınevi.

[34] Internation Telecommunication Union (ITU) (2012). Measuring the Information Society.

[35] Kalıpsız, O., Buharalı, A., Biricik, G. (2006) Bilgisayar Bilimlerinde Sistem Analizi ve Tasarımı Nesneye Yönelik Modelleme, İstanbul: Papatya Yayıncılık Eğitim.

[36] Karadede, A., Baykoç, F. Ö. (2006) Kurumsal Kaynak Planlaması Sonrası İşletmelerin Yaşadığı Sorunlar. Gazi Üniversitesi, Müh. Mim. Fakültesi Dergisi, Cilt. 21, No. 1.

[37] Kelly, O. (2007). Moving to Blended Delivery in a Polytechnic: Shifting the Mindset of Faculty and Institutions. Making the Transition to E-Learning: Strategies and Issues. Hershey, PA: Information Science Publishing.

[38] Kuh, G. ve Whitt, E. (1988). The Invisible Tapestry: Culture in American Colleges and Universities. Washington, DC: Association for the Study of Higher Education.

[39] Laudon, C. K. ve Laudon, J. P. (2007) Management Information Systems: Managing the Digital Firm. Tenth Edition, New Jersey: Prentice Hall.

[40] Layder, D. (1993). New Strategies in Social Research: An Introduction and Guide. Cambridge: Polity.

[41] Lawrence, P. R. ve Lorsch, J. W. (1967). Organization and Environment: Managing Differentiation and Integration. Homewood: Irwin.

[42] Lewis, T., Marginson, S. ve Snyder, I. (2005). The Networked University? Technology, Culture and Organisational Complexity in Contemporary Higher Education. Higher Education Quarterly.

[43] Mackay, H. (1991). Technology as an Educational Issue: Social and Political Perspectives. In H, Mackay, M. Young \& B. John (Eds.). Understanding Technology in Education, 1-12, New York: The Falmer Press.

[44] Massey, W. ve Zemsky, R. (1995). Using Information Technology to Enhance Academic Productivity. Washington, D.C.: Edcom. 
[45] Martin, W. (1988). The Information Society. London: Aslib.

[46] Meyer, J. W. ve Scott, R. S. (1992). Organizational Environments: Ritual and and Rationality. Newbury Park: Sage.

[47] Michael S. ve Holdaway, E. (1992). Entrepreneurial Activities in Postsecondary Education. The Canadian Journal of Higher Education.

[48] Miles, R. (1980). Macro Organizational Behavior. Glenview, Ill.: Scott, Foresman \& Company.

[49] Neave, G. ve Vught, F.A.V. (1994). Government and Higher Education in Developing Nations: A Conceptual Framework. Government and Higher Education Relationships Across three Continents: The Wind of Change, 1-21. New York: Pergamon.

[50] Noble, D. (1998). Digital Diploma Mills: The Automation of Higher Education. Monthly Review.

[51] ORACLE. Erişim: 11.08.2014. http://www.oracle.com/index.html.

[52] Özbilgin, G. ve Çalış, K. (2013). Bilgi ve İletişim Teknolojileri Açısından Türkiye ve Azerbaycan'ın Genel Karşılaștırılması

[53] Postman, N. (1992). Technopoly: The Surrender of Culture to Technology. New York: Alfred A. Knopf.

[54] Price, S. ve Oliver, M. (2007). A Framework for Conceptualizing the Impact of Technology on Teaching and Learning. Educational Technology \& Society.

[55] Ransom, W., Graham, C. ve Mott, J. (2007). Faculty Perceptions of Technology Projects. Educause Quarterly, 4.

[56] Stromquist, N ve Samoff, J. (2000) Knowled Ge Management Systems: On The Promise And Actual Forms Of Information Technologies. British Association for International and Comparative Education, Cilt. 30, No. 3.

[57] Teichler, U. (1991). The Federal Republic of Germany. Prometheus Bound: The Changing Relationship Between Government and Higher Education in Western Europe, 29-49, New York: Pergamon.

[58] Telem, M. (1993) Information Technology: A Missing Link In Educational Research. Journal of Research on Computing in Education. Fall 1993, Cilt. 26.

[59] Weizenbaum, J. (1976). Computer Power and Human Reason: From Judgment to Calculation. New York: W.H. Freeman and Company.

[60] WGDOL (2003). Technological Infrastructure and Use of ICT in Education in Africa: An Overview. Paris: Working Group on Distance Education and Open Learning of the Association for the Development of Education in Africa.

[61] WGDOL (2002). Distance Education and Open Learning in sub-Saharan Africa: A Literature Survey on Policy and Practice. Paris: Working Group on Distance Education and Open Learning of the Association for the Development of Education in Africa.

[62] Visscher, A., Wild, P., Smith, D. ve Newton, L. (2003) Evaluation Of The Implementation, Use And Effects Of A Computerised Management Information System In English Secondary Schools. British Journal of Educational Technology Cilt. 34, No. 3.

\footnotetext{
*Corresponding author.

E-mail address: hates@ thk.edu.tr
} 